IZA DP No. 4554

What Do Unions Do to Temporary Employment?

Andrea Salvatori

November 2009 


\title{
What Do Unions Do to Temporary Employment?
}

\author{
Andrea Salvatori \\ ISER, University of Essex \\ and IZA
}

\section{Discussion Paper No. 4554 \\ November 2009}

\author{
IZA \\ P.O. Box 7240 \\ 53072 Bonn \\ Germany \\ Phone: +49-228-3894-0 \\ Fax: +49-228-3894-180 \\ E-mail: iza@iza.org
}

\begin{abstract}
Any opinions expressed here are those of the author(s) and not those of IZA. Research published in this series may include views on policy, but the institute itself takes no institutional policy positions.

The Institute for the Study of Labor (IZA) in Bonn is a local and virtual international research center and a place of communication between science, politics and business. IZA is an independent nonprofit organization supported by Deutsche Post Foundation. The center is associated with the University of Bonn and offers a stimulating research environment through its international network, workshops and conferences, data service, project support, research visits and doctoral program. IZA engages in (i) original and internationally competitive research in all fields of labor economics, (ii) development of policy concepts, and (iii) dissemination of research results and concepts to the interested public.
\end{abstract}

IZA Discussion Papers often represent preliminary work and are circulated to encourage discussion. Citation of such a paper should account for its provisional character. A revised version may be available directly from the author. 
IZA Discussion Paper No. 4554

November 2009

\section{ABSTRACT}

\section{What Do Unions Do to Temporary Employment?*}

In the EU, one in seven employees work on temporary contracts associated with lower pay and less training. Using workplace-level data from 21 countries, I show that, in contrast with previous evidence for the US, unionized workplaces are more likely to use temporary employment across Europe. To address the endogeneity of unions, I then use a British dataset and exploit variation over time and across occupations to control for workplace unobserved heterogeneity. This confirms that unions contribute to creating contract duality in the labour market and thus do not limit the ability of firms to adjust employment through flexible contracts.

JEL Classification: J41, J51

Keywords: temporary employment, unions, panel data

Corresponding author:

Andrea Salvatori

Institute for Social \& Economic Research

University of Essex

Colchester CO4 3SQ

United Kingdom

E-mail: asalva@essex.ac.uk

\footnotetext{
* I thank prof. Mark Stewart and prof. Andrew Oswald for many useful discussions. I also thank Wiji Arulampalam, Robin Naylor, Jennifer Smith and participants at seminar at Warwick, UCL Louvain, SOLE 2009 Annual Conference.
} 


\section{Introduction}

Temporary employment is one of the distinctive features of contemporary European labour markets. Over the 90's, it accounted for most of the employment growth in Germany, Italy and France (OECD, 2002) and today around 14\% of EU employees work on contracts of limited duration. A dramatic increase in the spread of temporary employment has also been observed in the US where, between 1979 and 1995, agency employment grew five times faster then overall employment (Autor, 2003). Previous studies have shown that temporary employees are paid less, receive less training and report lower satisfaction than workers with similar observable characteristics on permanent contracts in the UK (Booth et al., 2002; Arulampalam and Booth, 1998; Arulampalam et al., 2004) and in other countries (OECD, 2002; Kahn, 2007; Arulampalam et al., 2004; Brunello et al., 2007). There is also some evidence of a negative wellbeing effect of temporary contracts (OECD, 2008) and concerns have been raised that a large share of temporary employment could be welfare reducing (Kahn, 2007). Some studies have found evidence that a temporary job can be a stepping stone towards a permanent one in Europe (Booth et al., 2002; Ichino et al., 2008), but not in the US (Autor and Houseman, 2002, 2008). Even for Europe, however, the data suggest that individuals with lower education struggle to make the transition to more stable jobs (OECD, 2008; Guell and Petrongolo, 2007).

It is therefore not surprising that in recent years temporary employment has increasingly attracted the attention of both Economists and policy makers, with growing effort dedicated to study the reasons behind its widespread use. Earlier contributions have uncovered evidence that the firing costs entailed by Employment Protection Legislation (EPL) for permanent workers encourage firms to use less-protected temporary workers (Booth et al., 2002; Blanchard and Landier, 2002; Autor, 2003; Kahn, 2007). This paper focuses on the role of another important feature of European labour markets presenting some similarities with EPL, i.e. unions. In fact, unions are known to disproportionately represent permanent workers $^{1}$ and, like firing costs, increase the bargaining power of employees.

If a union represents mainly permanent insiders, it might accept or encourage the use of temporary employment as a buffer for its members. Unions can also increase the de facto firing cost for permanent workers, either by directly bargaining over severance pay or by assisting workers facing the risk of dismissal therefore providing an incentive for the firm to use temporary contracts. Firms can also try to react to union wage pressure by employing cheaper temporary workers. On the other hand, a union can be reluctant to accept the use of temporary employees because they are less likely to be union members. The overall effect of unions on the probability of using temporary employment is therefore a priori ambiguous.

Besides furthering our understanding of one the main features of modern European labour

\footnotetext{
${ }^{1}$ The overwhelming evidence on this point is described later in the paper.
} 
markets, this paper also provides new insights on the ability of firms to adjust employment in the presence of unions. The macroeconomic implications for price hystheresis of employment adjustment costs have been emphasized, among others, by Hamermesh (1996) and Layard et al. (2005). It has been suggested that unions limit the flexibility of firms in managing employment reductions (Booth, 1995), but Hamermesh (1996) points out that a union representing the median worker will decrease the relative costs to employers of changing the employment of junior workers. This latter observation is consistent with the evidence that layoffs are not less frequent in unionised sectors (Medoff, 1979). Since temporary employment can be used by firms to adjust labour more easily, the analysis of the effects of unions on firms employment flexibility must also take into account this additional channel. Based on two US studies, Verma (2003) concludes that unions reduce flexibility, but the relevance of such a finding for Europe is unclear given the institutional differences between the two labour markets.

The analysis begins with data from the Establishment Survey on Working Time and Work-Life Balance (ESWT) covering workplaces from 21 European countries. While the vast majority of the literature on the determinants of temporary employment is based on data on individual workers, there is evidence that in most European countries temporary employment is largely involuntary ${ }^{2}$, suggesting that firms rather than workers play an important role in the decision to use temporary contracts.

The analysis based on ESWT provides the first evidence that across Europe unionised workplaces are more likely to use temporary employment. In order to try and address the potential endogeneity of union status, I then turn to a dataset that offers other sources of identification at the cost of having to restrict attention to a single country, the UK. I exploit different features of the Workplace Employment Relations Survey (WERS) including potential instruments and some longitudinal variation in the data. Furthermore, I implement a novel approach to WERS that takes advantage of the availability of information on individual occupations within a workplace. In particular, I rearrange the dataset so that each occupation in a given workplace becomes the unit of observation. This results in a dataset with repeated observations for each workplace that allows the use of the standard within-group estimator to remove the effect of workplace-level unobservable variables.

Overall, the evidence indicates that workplace unionisation increases the probability of using temporary employment. The European data show an average effect on the probability that a workplace uses fixed-term (agency) workers of $5 \%(3 \%)$, but estimates from WERS suggests even larger effects. There is generally no evidence of any effect when bargaining does

\footnotetext{
${ }^{2}$ Data available from Eurostat suggests that more than half of employees working on a temporary contract in the EU are doing so because they could not find a permanent job (data for 2004, 2005 and 2006). Data from the UK Labour Force Survey show that around a quarter of all British temporary workers would rather work on a permanent contract. Among agency workers alone, the proportion is above $40 \%$.
} 
not take place at the workplace, with the exception of a negative effect of organization-level bargaining on the probability of fixed-term workers in the largest occupation.

\section{Theoretical considerations}

There is substantial evidence that temporary workers are less unionized than permanent workers. Labour Force Survey data for the UK show that only $18 \%$ of temporary workers are union members as opposed to around 30\% of permanent workers ${ }^{3}$. Data from the 2004 wave of the European Social Survey suggests that only $12 \%$ of British workers on contracts of limited duration are union members, while more than $22 \%$ of permanent workers are. Noticeable differences are observed even in countries with traditionally high union membership such as Sweden (68\% for permanent workers, $51 \%$ for temporary workers), Norway (59\% vs $28 \%$ ) and Finland (60\% vs 46\%). Hence, it seems legitimate to assume that unions only represent permanent workers. The dominance of permanent workers' interests in the union objective function can easily be rationalize within a median-voter model of union preferences.

A standard right-to-manage model where the wage is set by Nash bargaining predicts that the wage will be an increasing function of the union strength (Booth, 1995). Hence, a union representing permanent workers will increase their relative cost leading the firm to use more temporary employment. The union can even directly benefit from the presence of temporary workers, since they enter the production function but do not appropriate any of the resulting rents. This point has been noted in the insider-outsider model where the outsiders' wage is not bargained over (Cahuc and Zylberberg, 2004).

Consideration of a multiperiod setting provides further intuitions. Firstly, unions can increase the expected firing cost for permanent workers leading the firm to hire more temporary workers. This can happen either because the union bargains over severance pay (Booth, 1995; Cahuc and Zylberberg, 2004) or because it simply provides workers with assistance in case of dismissal. Also, in a world with uncertainty following the wage bargaining process, temporary workers might provide a buffer for permanent workers (Bentolila and Dolado, 1994).

Finally, since temporary workers are less unionized and can reasonably be assumed to be less likely to engage in industrial actions, the presence of temporary workers can undermine the union strength. On the other hand, firms that intend to undermine the union strength may be more likely to resort to temporary workers. The overall effect of unions on the probability of employing temporary workers is therefore a priori ambiguous.

\footnotetext{
${ }^{3}$ Data from the Quarterly Labour Force Survey, Household dataset, 2004.
} 


\section{Empirical literature}

A small number of papers dedicated to temporary employment has touched upon the relationship between temporary employment and unions. For example, Kahn (2007) uses data on workers from seven countries and find that the positive effect of EPL on the incidence of temporary employment for some demographic groups is stronger where collective bargaining coverage is higher. Data on British individuals also reveal a small negative correlation or no correlation at all between working on a temporary contract and the probability of being covered by union bargaining (Francesconi and Garcia-Serrano, 2004; Booth and Francesconi, 2003). This paper differs substantially from these earlier contributions in that it uses data on workplaces rather than individuals. The fact that a large share of temporary employment appears to be involuntary ${ }^{4}$ suggests that firms' characteristics may play an important role in explaining the use of limited-duration contracts.

Using data on Spanish firms, Francesconi and Garcia-Serrano (2004) find no evidence of a link between the share of temporary employment and workplace unionisation. Bryson (2007) uses data from the 2004 wave of WERS and finds a weak positive correlation between unions and the use of agency workers. This paper uses workplaces data from across Europe and from the UK to present the first evidence for almost the whole of the EU and to try and address some of the possible limitations of these previous studies arising from the potential endogeneity of union status.

Two other studies have considered samples of firms from the US where temporary employment is less widespread than in Europe. Gramm and Schnell (2001) use a sample of less than 100 firms from the state of Alabama and finds a negative correlation between union coverage and the probability of using temporary employees in the main occupational group. Houseman (2001) uses a sample of more than 500 firms from the US and reaches the same conclusion. Finally, using aggregate data for the US states, Autor (2003) shows that the growth of agency employment was faster in states where unions declined more slowly.

\section{Empirical strategy}

In order to try and address the potential endogeneity of union status, this paper exploits several sources of identification from two different datasets. The analysis begins with data from the Establishment Survey on Working Time and Work-Life Balance (ESWT) which provides detailed data on a large sample of establishments from 21 European countries. While this allows to present the first empirical evidence on the relation between unionisation and temporary employment across European firms, the causal interpretation of the estimates

\footnotetext{
${ }^{4}$ In the sense that a large proportion of temporary workers across Europe say that the reason why they work on a temporary contract is that they could not find a permanent one.
} 
rests on the assumption that union status is exogenous conditional on the available covariates. Hence, I then turn to another dataset, the Workplace Employment Relations Survey (WERS), which allows alternative identification strategies at the cost of having to restrict the focus to a single country, the UK.

WERS has several important features. In the first place, its broad scope allows the adoption of a finer specification, therefore making the assumption of conditional exogeneity of union status more credible than with the European dataset. Second, it provides information useful to test for exogeneity of union status and enables me to exploit (i) variation over time and (ii) across occupations to remove the effect of workplace-level confounders. This appears the first paper to exploit this latter aspect of WERS. Finally, for each occupation within a workplace, WERS allows to see the level at which collective bargaining takes place (if at all). This is a very useful piece of information given the evidence that workplace characteristics tend to play a more important role when bargaining is decentralized (Layard et al., 2005).

\subsection{The endogeneity of union status}

Since temporary workers are less likely to be union members, their presence could decrease the likelihood that a workplace becomes unionized. Union status could, therefore, be endogenous in an equation for temporary employment due to reverse causality. A counterobjection is that union status is a structural feature of the firm unlikely to be affected by the decision to hire temporary workers which can be reverted in every period. In section 6.1 , I discuss the validity of lagged employment as an instrument and then use it to test for evidence against the assumption of exogeneity. Since the validity of such tests stems from the validity of the instrument itself, the reassuring results of these tests cannot be taken as definite. Unfortunately, nothing more can be done to tackle the issue of reverse causality using WERS, but other features of the dataset can be exploited to try and address other sources of endogeneity.

A major threat to the exogeneity of union status arises from possible unobservable variables which might be correlated with both union status and the propensity to use temporary employment. I try to address this issue in two different ways. First, I use the longitudinal variation in WERS to control for time-invariant heterogeneity across workplaces. In this framework, I discuss the strong exogeneity assumption (conditional on the fixed-effects) and conduct a simple test suggested by Wooldridge (2002). The models and the results using panel data are described in detail in section 6.2 .

Second, I propose a novel use of the dataset that fully exploits the availability of information on occupations within a given firm, a previously neglected aspect of WERS. In particular, I rearrange the dataset so that each occupation within a firm becomes the unit of observation. That makes it possible to apply standard panel data models to a sample where each firm (the equivalent of an individual in standard panel data) is observed in several 
occupations (time periods). By using the within-group estimator, I then effectively remove any firm-level confounders while also allowing the effect of observable firm characteristics to differ across occupations by suitable interaction terms. The details on this last step of the empirical analysis are provided in section 6.3.

All the estimates are obtained from linear probability models. This seems a relatively mild restriction given the discrete nature of most of the regressors included in the econometric specifications (Angrist, 2001; Wooldridge, 2002) and has clear advantages on terms of interpretation. The argument for a linear model is even stronger for the longitudinal and within-firm analysis of sections 6.2 and 6.3 where fixed-effect estimators are employed. In fact, while nonlinear models could be used, a probit model would yield inconsistent estimates due to the incidental parameter problem and the logit model would not allow estimation of the marginal effects of interest exactly because of the lack of assumptions on the distribution of the unobservables.

\section{The use of temporary employment in European firms}

\subsection{Data}

The Establishment Survey on Working Time and Work-Life Balance (ESWT) is a unique dataset covering a sample of more than 21000 workplaces from the EU-15 countries and 6 of the new members which joined in 2004 (the Czech Republic, Cyprus, Hungary, Latvia, Poland and Slovenia) $)^{5}$. Among other things, the management is asked whether any fixedterm workers and agency workers were employed in the workplace in the 12 months before the survey. As for unions, the ESWT provides information on workers' representation at the workplace. The national questionnaires consider the main forms of representation in each country which can be grouped into two broad categories: unions and works councils. The main difference between the two is that works councils are generally elected by all workers rather than just union members. The available empirical literature indicates that works councils and unions do not differ substantially in their effects. For example, studying German works councils, Addison et al. (2006) find that they increase wages, even after controlling for higher-level collective bargaining. It is also known that in most countries where works councils are the main form of representation, they are dominated by union members (ETUI-REHS, 2008; Addison et al., 2006). Hence, formal differences in workplace representation are unlikely to pose serious problems for my analysis and in this section I will use the word "union" with reference to any form of workplace representation recorded in the dataset.

\footnotetext{
${ }^{5}$ The sample is representative of all non-agricultural establishments with at least 10 employees. Interviews were conducted in 2004 for the EU-15 countries and in 2005 for the remaining ones.
} 
The role of workplace representation does vary greatly across countries, and sometimes even within countries. To see if noticeable differences are found depending on the importance of workplace representation in different nations, I look at the estimates for countries grouped by a centralization index which indicates the most important level at which collective bargaining takes place. I use the most recent version of the index produced by OECD (2004) which refers to the year 2000.

Table 1 reports the share of workplaces which used fixed-term workers in the 12 months before the survey for each of the 21 European countries by union status. With the only exception of Hungary, in every single country fixed-term workers are more commonly used in firms with workplace representation. Looking at the 21 countries together, the proportion of workplaces with fixed-term workers is roughly $50 \%$ when there is no workplace representation and $67 \%$ when there is some representation.

Table 9 shows the figures for the use of agency workers. Again, unionized workplaces are more likely to use agency workers in any country except for Portugal, Poland and Slovenia. Overall, $20 \%$ of non-union workplaces use agency workers against $36 \%$ of unionized workplaces.

\subsection{Econometric specification and the model}

I now estimate a multivariate model for the probability that a firm uses temporary employment. The ESWT offers a relatively large set of controls: firm size (dummies), industry dummies, dummy for independent establishment (rather than part of a larger company), dummy for being the head of a larger organization, dummies for the share of skilled workers. In addition, the survey asked managers whether the workplace has to cope with "major variations" in the workload within different time spans and whether such variations are foreseeable. This allows controlling for uncertainty therefore removing a possible source of bias in the effect of union on the use of temporary employment. In fact, uncertainty is likely to be a determinant of temporary employment, but it can also be correlated with union status if workers promote unions to make their jobs safer. The ESWT also contains information on whether the workplace faces difficulties in finding skilled or unskilled workers which could be correlated with temporary employment if limited-duration contracts are used to screen workers. Finally, I can also use a number of other variables which are likely to be correlated with temporary employment but can, at the same time, be suspected of endogeneity. I do check the robustness of the results to the introduction of the following variables: a dummy for a high absence rate, a dummy for difficulties in retaining workers, share of workers under the age of 30 and above 50, share of female workers and share of employees working overtime. 


\subsection{Results for the EU and by country}

The top panel of table 3 shows that unions are associated with a $5 \%$ increase in the probability of using fixed-term workers in the EU-15. Albeit still positive, the effect is smaller and statistically insignificant in the 6 new EU members (column 2). The second panel of table 3 looks at the use of agency workers. The estimated effect of union is a statistically significant $3 \%$ in the EU-15, but a statistically insignificant $-1.3 \%$ for the new members ${ }^{6}$.

Table 4 reports the estimate of the union coefficient in an equation for the use of fixed term workers by country. Countries are grouped by the centralisation index of OECD (2004) which indicates the most important level of bargaining in each country. In all but three of the 21 countries considered the partial correlation between unions and the use of temporary employment is positive. However, only in four countries is the coefficient on union statistically significant at least at the $10 \%$ level: Italy $(+15 \%)$, Austria $(+10 \%)$, Sweden $(+10 \%)$ and Ireland $(+16 \%)$. The $\mathrm{UK}^{7}(-3.5 \%)$, the Netherlands $(-3 \%)$ and Cyprus $(-5.7 \%)$ are the countries where union attracts negative coefficients which, however, are never statistically significant. There is no apparent trend in the effects of unions as centralisation of the national bargaining system increases, although a simple regression of the estimated coefficients on the index reveals a weak positive correlation between the two.

The effect of workplace unions on the use of agency workers is found negative in 9 countries out of 21 (table 5). In two of these the coefficient is actually almost exactly zero (Denmark and Spain), while in Poland (-4.5\%) and Portugal (-13.2\%), it is statistically significant at least at the $10 \%$ level. In the remaining five countries, including the $\mathrm{UK}^{8}$, the union coefficient is statistically insignificant. Among the 12 countries where union is positively correlated with the use of agency workers, the coefficient is statistically significant only in Italy $(+6.7 \%)$, Ireland $(+12.2 \%)$ and Greece $(+17.2 \%)$. The p-value for union in Germany $(+6.5 \%)$ is just above 0.10 . No clear pattern in the effect of union across different levels of centralisation appears and a simple bivariate regression confirms that the correlation between the union coefficients and the centralisation index is almost exactly zero.

In conclusion, these estimates indicate that the $5 \%$ effect of union on the probability of using fixed-term workers reflect a general positive correlation which is found in most countries. For agency workers, on the other hand, the $3 \%$ effect seems to be the average of rather different effects across countries.

\footnotetext{
${ }^{6}$ None of the EU-level estimates are sensitive to the inclusion of the OECD indicators for employment protection legislation, restrictions to fixed-term contracts and restrictions to temporary agency workers. These results are available from the author.

${ }^{7}$ The point estimate of the union effect for the UK appears to be sensitive to the specification adopted. In particular, when the dummy for independent establishment is excluded, a number of different specifications actually yield a positive, small and statistically insignificant coefficient.

${ }^{8}$ For the probability of employing agency workers, the point estimates of the union effect in the UK are not very sensitive to the specification adopted. In fact, they are always negative, but small (around -1\%) and statistically insignificant.
} 


\section{Using a British dataset to address the endogeneity of union status}

I begin this part of the analysis with data from the 2004 wave of WERS. The sample is restricted to workplaces in the private sector with more than 10 employees. Based on the information available in this wave of WERS, I can build two (dummy) measures of unionisation:

1. PresUnionMembers: 1 if there are some union members at the workplace;

2. UnionRecog: 1 if there is at least one union recognised at the workplace or at a higher level in the same firm.

It is not obvious which measure should be preferred. The dummy UnionRecog leaves unclear the level at which the union is recognised and even more the level at which bargaining actually takes place ${ }^{9}$. On the other hand, the dummy PresUnionMembers is certainly an indicator of the presence of a union at the workplace, but it does not necessarily imply that the union is actually recognised and involved in bargaining ${ }^{10}$.

Table 6 reports the share of private sector workplaces which use temporary employment broken down by these two definitions of union status. The UK estimates from WERS are considerably smaller than those from ESWT. This is probably due to the fact that while WERS asks whether any temporary workers are currently employed at the firm, ESWT asks whether any temporary employees were employed in the 12 months before the survey. The share of workplaces using fixed-term workers is $23 \%$ (46\% in ESWT) while that using agency workers is $14 \%(31 \%)$. The WERS figures, however, do confirm that unionised firms are more likely to use either form of temporary employment, regardless of the precise definition of union status. For example, the row for union recognition indicates that $32 \%$ of unionised workplaces and $22 \%$ of non-unionised workplaces employ fixed-term workers. Agency workers, on the other hand, are used in $24 \%$ of unionised firms but only in $13 \%$ of non-unionised ones.

\footnotetext{
${ }^{9}$ Recall that the union variable from the ESWT was defined as the presence of a recognised union at the workplace. So, although it did not consider recognition at other levels, even in that case the actual level of bargaining was unknown.

${ }^{10}$ The 2004 cross-section of WERS also allows to look at the effect of unions on the share of temporary employment. However, this is not possible with the European dataset, the panel element of WERS nor when occupational-level data from WERS are used. Hence, the paper focuses on the probability models. For completeness, I can report that preliminary OLS results show a very small and statistically insignificant positive effect of both measures of unionisation on the share of both fixed-term and agency workers. This can be taken as an approximate estimate of the average effect of unions on the whole population. For a discussion of the caveats of the causal interpretation of the estimates from linear models with a censored dependent variable see Angrist and Pischke (2009).
} 


\subsection{Cross-sectional analysis at the workplace-level}

WERS allows the use of the following control variables: total employment ${ }^{11}$, a dummy for independent establishments, a dummy for multiproduct firms, age of the establishment, regional and industry dummies, dummies for different market shares (between $5 \%$ and $10 \%$, 10-25, 25-50, more than 50\% and no external trade), dummies for regional, national and international market, a dummy for foreign competition, a dummy for whether demand depends only on price, a dummy for the presence of labour or overall cost targets, employment share of each occupation. To try and obviate the absence of firm-level measures of uncertainty in WERS, I attempt to identify clusters of firms facing similar degrees of (product market and/or labour market) uncertainty. I use two sets of interactions: one between industry and region and the other between industry and product market extension (regional, national or international). The former should help capture the effect of similar labour market uncertainty, whereas the latter that of product market uncertainty.

Even after including the set of controls just described, reverse causality and unobservable firm characteristics pose a threat to the exogeneity of union status. To test for any evidence against the exogeneity, I use the level of employment in 1998 to construct an instrument (Empl6Ago) for union status in 2004 and carry out a robustified regression-based Hausman test of the null of exogeneity ${ }^{12}$. For Empl6Ago to be a valid instrument, it must be partially correlated with union status in 2004 and be exogenous to the propensity to use temporary employment in 2004. Employment in 1998 can be expected to be correlated with union status in 2004 because the latter is a strongly persistent feature of the workplace and employment size is known to be a determinant of union status. Such correlation is confirmed by the firststage regressions reported below. Exogeneity of Empl6Ago holds under the mild assumption that the level of employment six years earlier has no direct effect on temporary employment once current employment is controlled for. This assumption seems plausible since the median duration of temporary contracts in the UK has been found to be of only 12 months (Booth et al., 2002 $)^{13}$. A potential objection is that large changes in employment levels might reflect higher uncertainty and would therefore be directly correlated with the propensity to use temporary employment. Although such an objection cannot be rejected with certainty, the

\footnotetext{
${ }^{11}$ If the square of total employment is included the coefficient on the union variables discussed below are only slightly smaller.

${ }^{12}$ The exogeneity tests were also conducted within a probit model using a test based on Rivers and Vuong (1988) and discussed in Wooldridge (2002). This is a test of the significance of the residuals from a linear regression of the endogenous variable on the instruments in a probit of dependent variable on all exogenous and endogenous regressors. The conclusions are the same obtained in the linear setting.

${ }^{13}$ They use data from the British Household Panel Survey from 1991 to 1997 . They also report that "almost all" temporary contracts have ended after 5 years. This is therefore even before new legislation came into effect in 2002 preventing any fixed-term contracts from lasting more than 4 years. It is interesting to note that in the document published in response to the consultation on such legislation, the Government observed that such constraint would affect mainly the public sector which accounts for the majority of people who have been in fixed-term employment for more than two years.
} 
aforementioned very short median duration of temporary contracts suggests that they are not used to deal with the sort of uncertainty captured by employment fluctuations over a 6-year period. To try and account for the role of uncertainty over a shorter time span, I check the robustness of the exogeneity tests to the inclusion of the set of interactions for uncertainty described above.

\subsubsection{Results}

Table 7 presents the estimates for the probability of using fixed-term workers. The unconditional estimates of columns 1 and 5 show that unionised firms are much more likely to use fixed-term workers. The difference is $+10 \%$ for union recognition and $+14 \%$ for union members. The introduction of several controls brings the estimates down to around $9 \%$ regardless of the definition adopted. The bottom panel of table 7 shows that, when firms characteristics are accounted for, the instrument Empl6Ago is strongly correlated with union status and there is no evidence against the null of exogeneity.

Column 1 of table 8 shows that he raw effect of union recognition on the probability of using agency workers is around $12 \%$, while that of the presence of union members is about $10 \%$. More than half of these differentials is explained by firm characteristics whose inclusion also reduces the precision of the estimates. The effect of union recognition remains slightly larger, never falling below $5 \%$ across specifications. In particular, a statistical significant effect of $7.5 \%$ is obtained when a full set of interactions are included in column 4 , while the $6.6 \%$ effect in column 3 is just on the verge of statistical significance at the $10 \%$ level. The estimate for union members is, on the other hand, around $3 \%$ and even when uncertainty is accounted for the $4 \%$ estimate remains statistically insignificant. Finally, the tests reported at the bottom of table 8 do not reveal any evidence against the null of exogeneity ${ }^{14}$.

Clearly, the validity of the exogeneity tests presented in this section critically hinges on the validity of the instruments employed. To further investigate the robustness of the OLS results, I now turn to other interesting features of WERS which can help to minimise the bias from unobserved confounders.

\subsection{Exploiting variation over time}

In this step of the analysis I use the panel element of WERS which contains data on more than 900 firms observed in 1998 and in 2004. When the sample is limited to the private sector, its actual size is slightly above 600 firms. I estimate a model in first-difference to remove the

\footnotetext{
${ }^{14}$ The inclusion of further controls for demographic characteristics of the workforce in the firm (share of women, younger and older workers) does not alter the conclusions for either type of temporary workers. Similarly, no substantial changes are observed when the share of days lost due to absence and the share of workers who voluntarily left the firm over the last year are included. These results are not reported here.
} 
effect of any time-invariant unobservable or omitted variables that could confound the effect of unions. For example, workplaces with workers-friendly human resources practices might be less prone to use temporary contracts and also more likely to recognize a union (assuming that workers dislike temporary contracts and like unions). The cost of this increased robustness is an inevitable loss of information likely to result in lower precision of the estimates.

Consistent estimation of the effect of union in this setting is based on the assumption of strict exogeneity. Such assumption rules out correlation between current shocks to temporary employment and current union status and also feedbacks from temporary employment in 1998 to union status in 2004. As pointed out by Wooldridge (2002) if union status is strictly exogenous then the union status in 1998 (or 2004) should not be significant in a first-difference regression for temporary employment. I present the results of this simple tests of exogeneity along with the main results.

\subsubsection{Econometric specification}

The dependent variable is a binary variable for employing temporary employees in a given firm. As for union status, I can use the same dummies as in the cross-sectional analysis: one for the presence of any union members in the workplace and one for any union recognised at the workplace or at a higher level. Because the 1998 cross-section questionnaire and the 2004 panel questionnaire were not identical, for some of the explanatory variables there are comparability issues across time. The regressors used and, where relevant, the problems encountered are discussed in 10. Here it suffices to say that the due to potential comparability issues, the panel analysis is conducted on two samples. One includes all available private sector workplaces, the other restricts the sample to workplaces which were trading externally in 1998.

\subsubsection{Results of first-difference estimation}

Table 9 presents the first-difference estimates for the probability of employing fixed term workers in the workplace. The point estimate for union recognition is negative across all columns, but always fails to reach statistical significance. Also the size of the estimates varies greatly depending on which sample is used. Some variation in the size of the coefficient across columns is also seen for union members, but the sign is consistently positive and statistical significance at the $5 \%$ is reached in three of the four cases considered. Precision is generally higher when the interactions for uncertainty are included, as one would probably expect. The (statistically significant) estimates from the specification with the interactions for uncertainty are $17 \%$ in the smaller sample and $12 \%$ in the larger one.

As a check of the validity of the first-difference estimates, the bottom panel of table 9 reports the results of the simple test for the strict exogeneity of union status suggested by 
Wooldridge (2002). The conclusion is consistent across samples and specifications: there is no evidence against the null of exogeneity.

The first difference results for the probability of agency workers in table 10 suggests that the effect of union recognition is positive. The point estimates exceed $20 \%$ and are statistically significant in the first sample, while they are closer to $15 \%$ in the larger sample where their p-values are not smaller than 0.16. The evidence on the effect of union members, on the other hand, is very clear. The coefficients are statistically well defined and their magnitude is not sensitive to the sample used. When uncertainty is not accounted for the effect is around $18 \%$ which increase to around $23 \%$ when the interactions with time are included as well. No evidence against the null of strict exogeneity of union status is found as shown in the bottom panel of table 10 .

\subsection{Within-workplace analysis to remove workplace-level confounders}

This section presents what appears to be the first attempt to fully take advantage of the availability of information on occupations within workplaces in WERS. Based on such information,the following variables can be defined for each occupation within a workplace:

1. a dummy for the presence of FixT and a dummy for agency workers;

2. three dummies indicating whether the pay a given occupation is set through negotiations at the industry, organization or workplace level. These dummies are called IndustryBarg, OrgBarg, and LocalBarg respectively;

3. a dummy for bargaining over pay taking place at any level. (AnyBarg);

4. a dummy for the presence of union members in the given occupation (UnionMemb).

To exploit variation across occupations in a given firm, I model the propensity of workplace $f$ to use temporary employment in occupation $o$ as:

$$
y_{f, o}=\alpha+\beta^{\prime} X_{f, o}+\Gamma^{\prime} F_{f}+\zeta_{f}+\varepsilon_{f, o}
$$

where $X_{f, o}$ is a vector of occupation-level characteristics, $F_{f}$ is a vector of workplacelevel characteristics (which are constant across occupations) and $\zeta_{f}$ is a workplace fixedeffect whose distribution is unrestricted. $\varepsilon_{f, o}$ is an unobservable affecting the probability of temporary workers in occupation $o$ in workplace $f$. The model is estimated using the within-firm estimator to allow the workplace-fixed effect (and any workplace-level omitted 
characteristics) to be arbitrarily correlated with the regressors ${ }^{15}$. The only occupational groups excluded is that of managers, leaving a maximum of 8 observations for each workplace.

The number of occupation-level controls included is forcefully restricted by data availability. Most of the occupation-level information available pertains to pay systems and it is not clear whether they should be included at all, but I do check the robustness of the results to the inclusion of these variables. I also extend the specification to allow the observable firm characteristics to have different effects on the largest occupation (LOC). In this specification I can also include additional occupation-level controls which are only available for the largest occupation. The linear model in equation 1 therefore becomes:

$$
y_{f, o}=\alpha+\beta^{\prime} X_{f, o}+\Gamma^{\prime} F_{f}+\phi_{1} L O C_{f, o}+\Phi_{2} L O C_{f, o} * K_{f, o}+\Delta^{\prime} L O C_{f, o} * F_{f}+\zeta_{f}+\varepsilon_{f, o}
$$

where $L O C_{f, o}$ is binary indicator for occupation o being the largest in firm $f ; K_{f, o}$ is a vector of occupation characteristics observed only for the largest occupation. Because of data limitations, I am forced to impose the strong assumption that such variables only matter for the largest occupation.

\subsubsection{Results for the within-workplace analysis}

The results of the within-firm estimates for the probability of employing fixed-term workers in a given occupation are reported in table 11. For each measure of unionisation, three different specifications are adopted ${ }^{16}$. First, equation 1 is estimated with controls for occupations, employment size within each occupation and a dummy for being the largest occupation (LOC). Second, interactions of the LOC dummy with all the firm-level variables previously employed are added. Third, controls for the share of workers that quit the firm in the last 12 months and for the percentage of days lost due to absence are included ${ }^{17}$. To help visualise the effect of unions in the LOC, table 12 presents the sum of the union coefficient plus the coefficient on the Union * LOC interaction along with a Wald test for the null that such

\footnotetext{
${ }^{15}$ All estimates are weighted to account for the complex design of WERS. The weights for the WERS cross-sectional dataset accounts for stratification. When the unit of observation is smaller than the firm, weights should also take into account the probability of selection within the firm. For example, the weights for the employees in the WERS dataset are the firm weights multiplied by the probability of selection of a given employee (Chaplin et al., 2004). Since each occupation within a given firm is selected into the "sample of occupations" with probability one (at least in the balanced sample), no additional correction is neccessarry in this case.

${ }^{16}$ The results of all three the specifications proved substantially insensitive to the inclusion of (occupationlevel) controls for performance pay, profit related pay, share ownership schemes, and job security guarantees. They are also robust to the inclusion of a set of interactions between (1) industry, regions and LOC and (2) industry, geographical extension of the market and LOC. Following the logic of the previous sections, such interactions are meant to account for clusters of firms facing similar uncertainty.

${ }^{17}$ These variables might well be one of the channels through which the effect of unions on temporary employment unfolds, but they can aslo be suspected of endogeneity. Hence, it is not obvious whether they should be included or not, especially if one is interested in a gross effect.
} 
overall effect is equal to zero.

The first column of table 11 shows that the effect of collective bargaining in a generic occupation is positive but practically negligible. Column 7 confirms that this is true irrespective of the level at which bargaining takes place. Within the largest occupation, however the level of bargaining seems to matter. In fact, although overall bargaining within the LOC attracts a negative and statistically insignificant coefficient in column 2 of table 11, in columns 8 and 9 organizational bargaining picks up a negative and significant coefficient which results in a net negative effect of around $-15 \%$ as reported in table 12 .

As for union members, I find a positive effect of $4.6 \%$ in a generic occupation (column 4 of table 11 ), with a p-value of 0.15 . There is some statistically very weak evidence that the effect of union members is slightly larger in the LOC (columns 5 and 6). The overall effect of union members in the LOC exceeds $7 \%$ in the longest specification, but its p-value is never below 0.14 (column 4 in table 12).

The results for the probability of agency workers in a given occupation are reported in table 13. Overall bargaining attracts a positive coefficient suggesting an effect just below $5 \%$ (column 1), but the estimate is statistically insignificant with a p-value around 0.18. Columns 2 and 3 show that the effect of bargaining is larger in the LOC, with an overall effect above $6 \%$ (table 14) which is also statistically insignificant. The dummies for bargaining at different levels in column 7 of table 13 indicate a $15 \%$ effect of workplace bargaining in a generic occupation. The estimate is even larger in the LOC, reaching $24 \%$ (table 14). There is also some evidence of a smaller effect of workplace bargaining outside the largest occupation of around $8 \%$ with a p-value just above 0.11 , but both the point estimate and its precision decrease when controls for quits and absences are included (columns 8 and 9 of table 13). On the other hand, there is no evidence of a positive effect of industry- or organization-level bargaining in the LOC, as they both attracts negative and highly insignificant coefficients.

The presence of union members increases the probability of agency workers in a generic occupation by a statistically significant $3 \%$ as shown in column 4 of table 13 . Columns 5 and 6 show that the evidence that the effect is larger in the LOC is statistically weak, but the estimates reported in table 14 suggest an overall effect of union members in the LOC of $4.1 \%$ $(\mathrm{p}=0.12)$ which is just below $7 \%(\mathrm{p}=0.02)$ when quit and absence rates are held constant ${ }^{18}$.

\section{$7 \quad$ Summary of the main results}

Consider first the evidence on fixed-term workers. The European data show that firms with workplace representation are more likely to use fixed-term workers. The large sixteen point

\footnotetext{
${ }^{18}$ The effect of union members is larger and estimated more precisely when the aforementioned set of interactions to account for uncertainty are introduced in the specification. The results for the other union measures do not change in noteworthy ways.
} 
differential in the raw data shrinks to a five points difference when confounding workplace characteristics are accounted for. A positive effect is found in 18 of the 21 countries considered, although the statistical precision of the estimates varies. I then used a British dataset, WERS, to try and deal with the potential endogeneity of union status. This dataset allows to define two indicators for the presence of a union: (i) a dummy for the presence of any union members at the workplace and (ii) a dummy for union recognition at the workplace or at a higher level. As for union members, the evidence of a positive effect is clear. Both the cross-section and longitudinal analysis support this conclusion. Also, in both cases simple tests reveal no evidence against the null of exogeneity of union status. The estimates that exploit variation across occupations are also positive but less precise. As for the size of the effects, it is difficult to draw a definite conclusion. In particular, the cross-section estimate is $8 \%$, but the panel and the occupation-level estimates differ in opposite directions. More insights could come from exploiting simultaneously these two sources of variation (over time and over occupations), but this is not possible with the current dataset.

When the dummy for union recognition (at any level) is used, the evidence is mixed. In fact, the positive coefficient of the cross-sectional analysis turns into a negative one in the longitudinal analysis. A statistically insignificant negative coefficient was also obtained in the British subsample of the EU dataset where unionisation was measured by the presence of a recognised union at the workplace. The results from the occupation-level analysis based on WERS may help explain these findings. For each occupation, in fact, the actual level at which bargaining over pay takes place is known. I obtain an imprecisely estimated negative coefficient for bargaining (at any level) in the largest occupation, but the breakdown of the bargaining levels reveals that this is entirely driven by organization-level bargaining. The effect of the latter is a well defined $-15 \%$. On the other hand, there is some weak evidence that industry and workplace bargaining have a small positive effect on the probability of fixedterm workers. This suggests that the negative but insignificant coefficients that I obtain for union recognition (at any level) might be driven by the negative effect of bargaining at the organization level.

Overall, it appears that whenever an indicator of the presence or activity of a union at the workplace is used (workplace representation in the ESWT, presence of union members or bargaining in the workplace in WERS), the evidence points to a positive effect on the probability of fixed-term workers, although with varying degrees of statistical precision.

A similar conclusion can be reached for the probability of using agency workers. In this case, the average European effect is around 3\%, with a positive effect found in 12 of the 21 countries. The British data again provide no evidence against the exogeneity of union status and the evidence of a positive effect of union members is clear across models, although again considerable differences are observed between the estimates exploiting variation over time and those exploiting variation across occupations. Also when unionisation is measured by a 
dummy for recognition (at any level) there is evidence of a positive effect. The occupationlevel estimates suggests that this is driven by a strong positive effect of workplace bargaining (around $+15 \%$ ) which appears to be even larger in the main occupation.

\section{Concluding remarks}

Using data from two datasets and exploiting several sources of identification, this paper has presented what appears to be the first empirical evidence of the effect of unions on the probability that firms use temporary employment across Europe. Overall, the evidence indicates that workplace unionisation increases the probability of using temporary employment. The European data indicate an average effect on the probability that a workplace uses fixedterm (agency) workers of $5 \%(3 \%)$. Such estimate is consistent with the smallest estimates obtained from the British dataset, although different models suggests much larger effects.

There is generally no clear evidence of an effect of unions when collective bargaining does not take place at the workplace, with the exception of a strong negative effect of organization-level bargaining on the probability that fixed-term workers are employed in the largest occupation. Such heterogeneity of the effects across different levels of collective bargaining is puzzling. It is possible that the models used in this paper are not suited to accurately capture the effect of bargaining at levels other than the workplace since they included almost exclusively controls for workplace characteristics.

The evidence of a positive effect of workplace unionisation is in contrast with previous findings for the US (Gramm and Schnell, 2001; Houseman, 2001) and shows that Verma (2003)'s conclusion that unions reduce flexibility cannot be extended to Europe. This result is important for macroeconomists who are concerned with the implications of employment adjustments costs for price hystheresis and the persistence of shocks (Hamermesh, 1996; Layard et al., 2005).

From the perspective of the research on modern labour markets, my finding supports the hypothesis that workplace unions, like firing costs, increase contract duality. An evaluation of the overall effect of unions on duality in the labour market, however, requires further research into how temporary workers are treated in unionised firms. Bentolila and Dolado (1994) do not find evidence that unions give weight to temporary workers' interests using Spanish firm-level data from the 1980's. More insights on this point could come from the use of individual (or, ideally, matched) data that enable the researcher to look at different outcomes of temporary and permanent workers separately.

Finally, the finding of this paper leaves open the question as to what are the channels through which the effect of unions on temporary employment unfolds. For instance, a positive effect could arise because union members benefit from the buffer effect provided by 
temporary workers or because firms hire less-unionised temporary workers to undermine the union's strength in bargaining. This is a particularly challenging empirical question for future research since it requires finding sources of exogenous shocks which might have activated each of these channels in isolation. 


\section{Tables}

Table 1: Share of workplaces employing fixed-term (FixT) workers by union status.

\begin{tabular}{|c|c|c|c|}
\hline Country & No Union & Union & Overall \\
\hline Belgium & 0.34 & 0.57 & 0.40 \\
\hline Denmark & 0.31 & 0.36 & 0.34 \\
\hline Germany & 0.40 & 0.65 & 0.46 \\
\hline Greece & 0.27 & 0.43 & 0.28 \\
\hline Spain & 0.63 & 0.69 & 0.66 \\
\hline France & 0.64 & 0.75 & 0.67 \\
\hline Ireland & 0.40 & 0.65 & 0.44 \\
\hline Italy & 0.46 & 0.66 & 0.51 \\
\hline Luxembourg & 0.34 & 0.48 & 0.41 \\
\hline Netherlands & 0.77 & 0.81 & 0.78 \\
\hline Austria & 0.21 & 0.41 & 0.26 \\
\hline Portugal & 0.89 & 0.92 & 0.89 \\
\hline Finland & 0.74 & 0.80 & 0.77 \\
\hline Sweden & 0.60 & 0.70 & 0.66 \\
\hline UK & 0.44 & 0.56 & 0.46 \\
\hline EU-15 & 0.49 & 0.67 & 0.54 \\
\hline Czech Rep & 0.92 & 0.96 & 0.93 \\
\hline Cyprus & 0.25 & 0.28 & 0.26 \\
\hline Latvia & 0.40 & 0.54 & 0.42 \\
\hline Hungary & 0.46 & 0.46 & 0.46 \\
\hline Poland & 0.62 & 0.85 & 0.63 \\
\hline Slovenia & 0.62 & 0.83 & 0.69 \\
\hline EU-21 & 0.51 & 0.67 & 0.55 \\
\hline
\end{tabular}

Private sector workplaces with more than 10 employees.

Weighted data from ESWT 2004/2005 
Table 2: Share of workplaces employing agency workers (TAW) by union status.

\begin{tabular}{lccc}
\hline \hline Country & No Union & Union & Overall \\
Belgium & 0.48 & 0.76 & 0.55 \\
Denmark & 0.28 & 0.31 & 0.30 \\
Germany & 0.15 & 0.33 & 0.19 \\
Greece & 0.03 & 0.20 & 0.05 \\
Spain & 0.20 & 0.29 & 0.25 \\
France & 0.34 & 0.58 & 0.41 \\
Ireland & 0.16 & 0.34 & 0.19 \\
Italy & 0.19 & 0.32 & 0.22 \\
Luxembourg & 0.22 & 0.42 & 0.33 \\
Netherlands & 0.43 & 0.57 & 0.48 \\
Austria & 0.17 & 0.32 & 0.20 \\
Portugal & 0.11 & 0.08 & 0.11 \\
Finland & 0.24 & 0.26 & 0.25 \\
Sweden & 0.15 & 0.24 & 0.20 \\
UK & 0.29 & 0.43 & 0.31 \\
& & & \\
EU-15 & 0.22 & 0.38 & 0.26 \\
& & & \\
Czech Rep & 0.10 & 0.14 & 0.10 \\
Cyprus & 0.07 & 0.05 & 0.07 \\
Latvia & 0.08 & 0.13 & 0.08 \\
Hungary & 0.06 & 0.09 & 0.07 \\
Poland & 0.03 & 0.02 & 0.03 \\
Slovenia & 0.61 & 0.61 & 0.61 \\
EU-21 & 0.20 & 0.36 & 0.24 \\
\hline \hline Private & & & \\
\hline
\end{tabular}

Private sector workplaces with more than 10 employees.

Weighted data from ESWT 2004/2005 
Table 3: Linear models for the probability of temporary workers in private sector establishments with more than 10 employees.

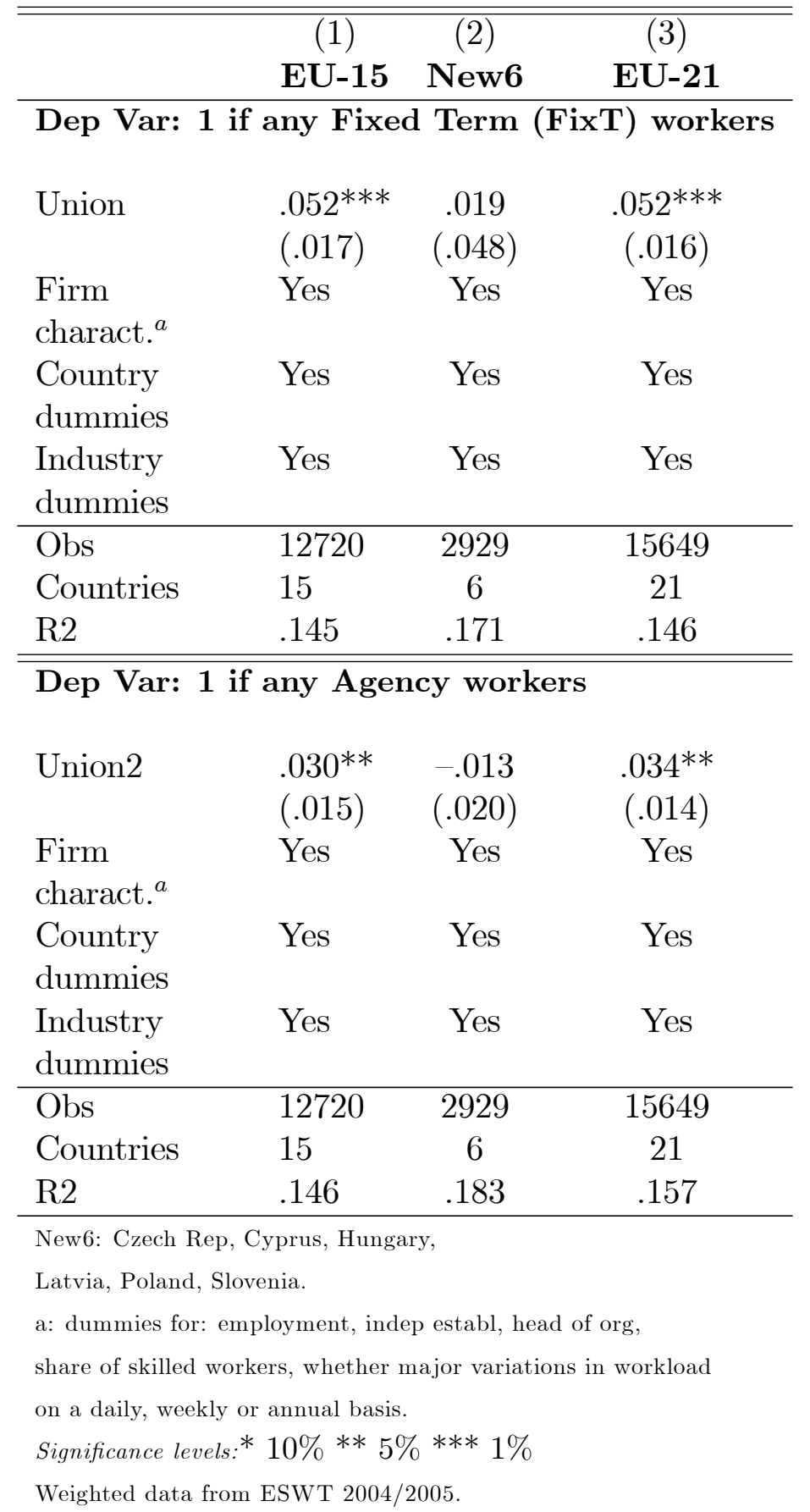


Table 4: Linear models for the probability of fixedterm (FixT) workers in each country, grouped by the centralisation index of OECD (2004).

\begin{tabular}{|c|c|c|c|}
\hline Country & Union & SE & Pvalue \\
\hline \multicolumn{4}{|c|}{ Company and plant level predominant } \\
\hline Hungary & 0.040 & 0.077 & 0.608 \\
\hline Poland & 0.016 & 0.076 & 0.838 \\
\hline Uk & -0.035 & 0.057 & 0.534 \\
\hline \multicolumn{4}{|c|}{ Industry and company level } \\
\hline Denmark & 0.039 & 0.050 & 0.435 \\
\hline France & 0.060 & 0.046 & 0.197 \\
\hline Italy & 0.147 & 0.044 & 0.001 \\
\hline \multicolumn{4}{|c|}{ Industry level predominant } \\
\hline Austria & 0.095 & 0.051 & 0.063 \\
\hline Belgium & 0.058 & 0.078 & 0.457 \\
\hline Germany & 0.049 & 0.048 & 0.308 \\
\hline Netherlands & -0.026 & 0.067 & 0.699 \\
\hline Spain & 0.001 & 0.042 & 0.983 \\
\hline Sweden & 0.098 & 0.056 & 0.084 \\
\hline \multicolumn{4}{|c|}{ Industry and central level } \\
\hline Ireland & 0.160 & 0.076 & 0.035 \\
\hline Portugal & 0.019 & 0.066 & 0.775 \\
\hline \multicolumn{4}{|l|}{ Central level } \\
\hline Finland & 0.030 & 0.043 & 0.483 \\
\hline \multicolumn{4}{|c|}{ Index not available } \\
\hline Cyprus & -0.057 & 0.063 & 0.368 \\
\hline $\begin{array}{l}\text { Czech Repub- } \\
\text { lic }\end{array}$ & 0.023 & 0.023 & 0.308 \\
\hline Greece & 0.113 & 0.088 & 0.202 \\
\hline Latvia & 0.127 & 0.122 & 0.299 \\
\hline Luxembourg & 0.098 & 0.096 & 0.312 \\
\hline Slovenia & 0.084 & 0.067 & 0.212 \\
\hline
\end{tabular}

Data from ESWT 2004-2005.

Private sector firms with more than 10 employees. 
Table 5: Linear models for the probability of agency workers (TAW) in each country, grouped by the centralisation index of OECD (2004).

\begin{tabular}{|c|c|c|c|}
\hline Country & Union & SE & Pvalue \\
\hline \multicolumn{4}{|c|}{ Company and plant level predominant } \\
\hline Hungary & 0.053 & 0.031 & 0.086 \\
\hline Poland & -0.045 & 0.016 & 0.005 \\
\hline Uk & -0.029 & 0.053 & 0.584 \\
\hline \multicolumn{4}{|c|}{ Industry and company level } \\
\hline Denmark & -0.000 & 0.045 & 0.991 \\
\hline France & 0.070 & 0.048 & 0.148 \\
\hline Italy & 0.067 & 0.041 & 0.100 \\
\hline \multicolumn{4}{|c|}{ Industry level predominant } \\
\hline Austria & 0.047 & 0.043 & 0.278 \\
\hline Belgium & 0.084 & 0.088 & 0.340 \\
\hline Germany & 0.062 & 0.038 & 0.105 \\
\hline Netherlands & -0.056 & 0.061 & 0.364 \\
\hline Spain & -0.000 & 0.032 & 0.995 \\
\hline Sweden & 0.056 & 0.043 & 0.197 \\
\hline \multicolumn{4}{|c|}{ Industry and central level } \\
\hline Ireland & 0.122 & 0.062 & 0.052 \\
\hline Portugal & -0.132 & 0.067 & 0.050 \\
\hline \multicolumn{4}{|l|}{ Central level } \\
\hline Finland & -0.055 & 0.040 & 0.169 \\
\hline \multicolumn{4}{|c|}{$\overline{\text { Index not available }}$} \\
\hline Cyprus & -0.028 & 0.044 & 0.528 \\
\hline $\begin{array}{l}\text { Czech Repub- } \\
\text { lic }\end{array}$ & -0.123 & 0.077 & 0.110 \\
\hline Greece & 0.172 & 0.084 & 0.041 \\
\hline Latvia & 0.032 & 0.087 & 0.712 \\
\hline Luxembourg & 0.009 & 0.103 & 0.928 \\
\hline Slovenia & 0.020 & 0.076 & 0.795 \\
\hline
\end{tabular}

Data from ESWT 2004-2005.

Private sector firms with more than 10 employees. 
Table 6: Share of workplaces using fixed-term (FixT) and agency (TAW) workers by union status.

\begin{tabular}{lcc}
\hline \hline & $(1)$ & $(2)$ \\
& FixT & TAW \\
\hline Total & 0.233 & 0.144 \\
& & \\
\hline \hline NoMembers & 0.197 & 0.119 \\
Members & 0.338 & 0.217 \\
Pearson-F & 18.930 & 15.772 \\
P-Value & 0.000 & 0.000 \\
& & \\
\hline \hline NoRecog & 0.218 & 0.126 \\
Recog & 0.320 & 0.243 \\
Pearson-F & 7.927 & 17.136 \\
P-Value & 0.005 & 0.000 \\
& & \\
\hline \hline
\end{tabular}

\footnotetext{
Private sector workplaces with more than 10 employees.

Data from Managment Questionaire of WERS 2004

Pearson-F tests independence between

use of fixed-term contracts and unionisation.
} 
Table 7: Linear models for the probability of fixed-term (FixT) workers in UK private-sector workplaces.

\begin{tabular}{|c|c|c|c|c|c|c|c|c|}
\hline & (1) & $(2)$ & $(3)$ & (4) & $(5)$ & $(6)$ & $(7)$ & $(8)$ \\
\hline UnionRec & $\begin{array}{l}.102^{* * *} \\
(.038)\end{array}$ & $\begin{array}{l}.080^{*} \\
(.045)\end{array}$ & $\begin{array}{l}.083^{*} \\
(.044)\end{array}$ & $\begin{array}{l}.088^{*} \\
(.046)\end{array}$ & & & & \\
\hline AnyUnionMemb & & & & & $\begin{array}{c}.141^{* * *} \\
(.034)\end{array}$ & $\begin{array}{c}.094^{* *} \\
(.039)\end{array}$ & $\begin{array}{l}.082^{* *} \\
(.041)\end{array}$ & $\begin{array}{l}.091^{* *} \\
(.042)\end{array}$ \\
\hline Firm charact. $^{a}$ & No & Yes & Yes & Yes & No & Yes & Yes & Yes \\
\hline Ind. Dummies & No & No & Yes & Yes & No & No & Yes & Yes \\
\hline Reg. Dummies & No & No & Yes & Yes & No & No & Yes & Yes \\
\hline Occup. Shares & No & No & Yes & Yes & No & No & Yes & Yes \\
\hline RegXInd & No & No & No & Yes & No & No & No & Yes \\
\hline IndXGeoMk & No & No & No & Yes & No & No & No & Yes \\
\hline Obs. & 1479 & 1208 & 1200 & 1200 & 1486 & 1210 & 1202 & 1202 \\
\hline \multicolumn{9}{|c|}{ Exogeneity Tests using Empl6Ago as an instrument } \\
\hline Obs. $^{b}$ & & 816 & 810 & 810 & & 816 & 810 & 810 \\
\hline 1st Stage F & & 1.301 & 13.417 & 9.394 & & 1.011 & 16.546 & 11.714 \\
\hline P-Value & & .254 & .000 & .002 & & .315 & .000 & .001 \\
\hline F for Ho:Exog & & 2.996 & .522 & .001 & & 2.892 & .526 & .001 \\
\hline P-Value & & .084 & .470 & .975 & & .089 & .469 & .974 \\
\hline \\
\hline \multicolumn{9}{|c|}{$\begin{array}{l}\text { a: Total employment, age, dummies: indep establ, multiproduct, mk shares, reg, nat, int mk } \\
\text { foreign comp, demand depends on price, cost targets. }\end{array}$} \\
\hline \multicolumn{9}{|c|}{ b: sample restricted to workplaces in operation in 1998 . } \\
\hline \multicolumn{9}{|c|}{ Significance levels: $* 10 \% * * 5 \% * * * 1 \%$. Weighted estimates, st. err. account for complex design. } \\
\hline
\end{tabular}


Table 8: Linear models for the probability of agency workers in UK private-sector workplaces.

\begin{tabular}{|c|c|c|c|c|c|c|c|c|}
\hline & (1) & (2) & (3) & (4) & (5) & (6) & (7) & (8) \\
\hline UnionRec & $\begin{array}{l}.118^{* * *} \\
(.032)\end{array}$ & $\begin{array}{l}.051 \\
(.037)\end{array}$ & $\begin{array}{l}.066 \\
(.041)\end{array}$ & $\begin{array}{l}.075^{* *} \\
(.036)\end{array}$ & & & & \\
\hline AnyUnionMemb & & & & & $\begin{array}{c}.098^{* * *} \\
(.026)\end{array}$ & $\begin{array}{c}.030 \\
(.029)\end{array}$ & $\begin{array}{c}.022 \\
(.033)\end{array}$ & $\begin{array}{c}.041 \\
(.033)\end{array}$ \\
\hline Firm charact. ${ }^{a}$ & No & Yes & Yes & Yes & No & Yes & Yes & Yes \\
\hline Ind. Dummies & No & No & Yes & Yes & No & No & Yes & Yes \\
\hline Reg. Dummies & No & No & Yes & Yes & No & No & Yes & Yes \\
\hline Occup. Shares & No & No & Yes & Yes & No & No & Yes & Yes \\
\hline RegXInd & No & No & No & Yes & No & No & No & Yes \\
\hline IndXGeoMk & No & No & No & Yes & No & No & No & Yes \\
\hline Obs. & 1482 & 1210 & 1202 & 1202 & 1489 & 1212 & 1204 & 1204 \\
\hline \multicolumn{9}{|c|}{ Exogeneity Tests using Empl6Ago as an instrument } \\
\hline Obs. & & 816 & 810 & 810 & & 816 & 810 & 810 \\
\hline 1st Stage F & & 1.301 & 13.417 & 9.394 & & 1.011 & 16.546 & 11.714 \\
\hline P-Value & & .254 & .000 & .002 & & .315 & .000 & .001 \\
\hline $\mathrm{F}$ for Ho:Exog & & .276 & .003 & .105 & & .143 & .036 & .057 \\
\hline P-Value & & .599 & .960 & .745 & & .706 & .850 & .811 \\
\hline
\end{tabular}

Dep Var: 1 if any agency workers, 0 if none.

a: Total employment, age, dummies: indep establ, multiproduct, mk shares, reg, nat, int mk foreign comp, demand depends on price, cost targets.

b: sample restricted to workplaces in operation in 1998.

Significance levels: ${ }^{*} 10 \% * * 5 \% * * * 1 \%$. Weighted estimates, st. err. account for complex design.

Data from WERS 2004, private sector firms with $>10$ employees. 


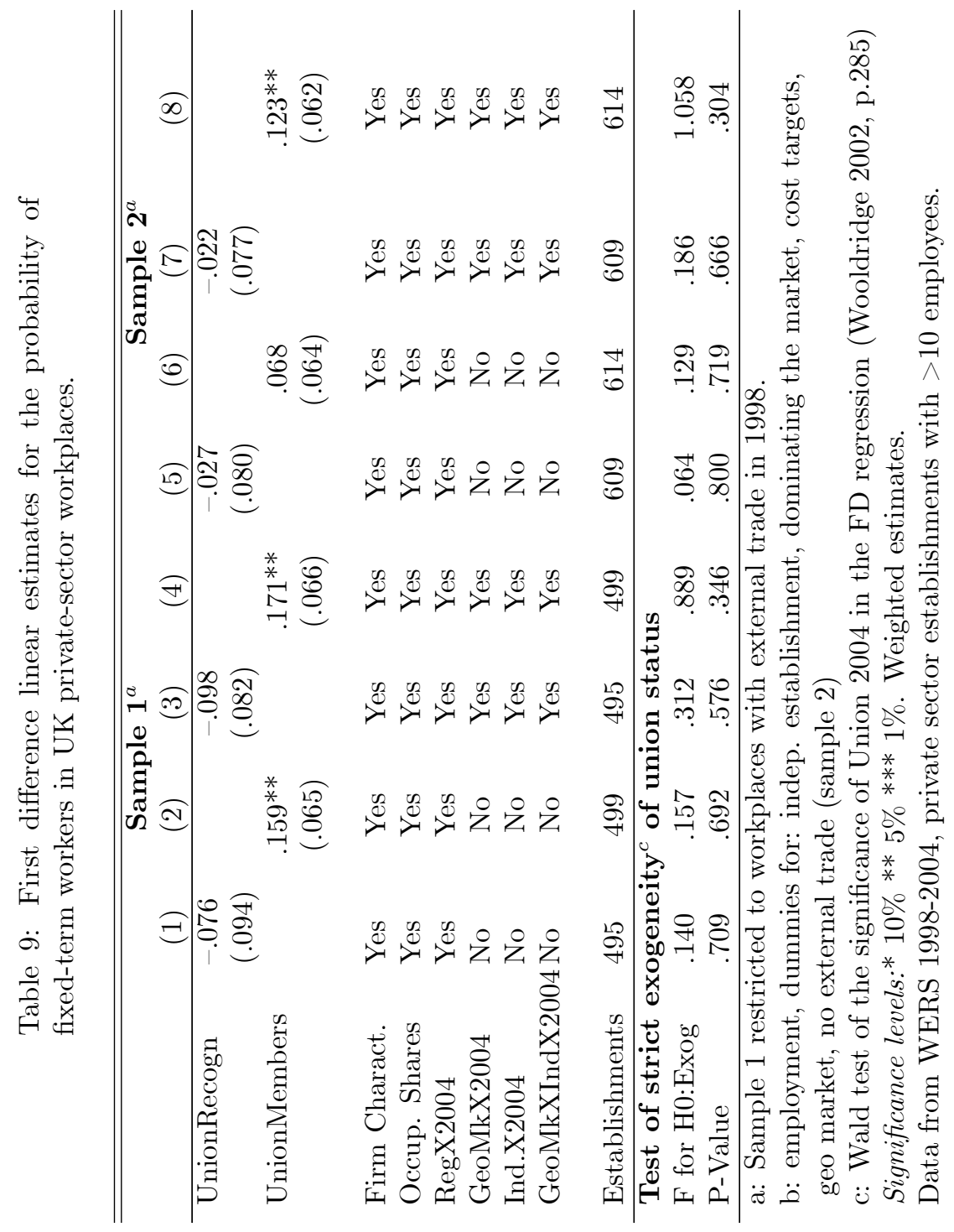




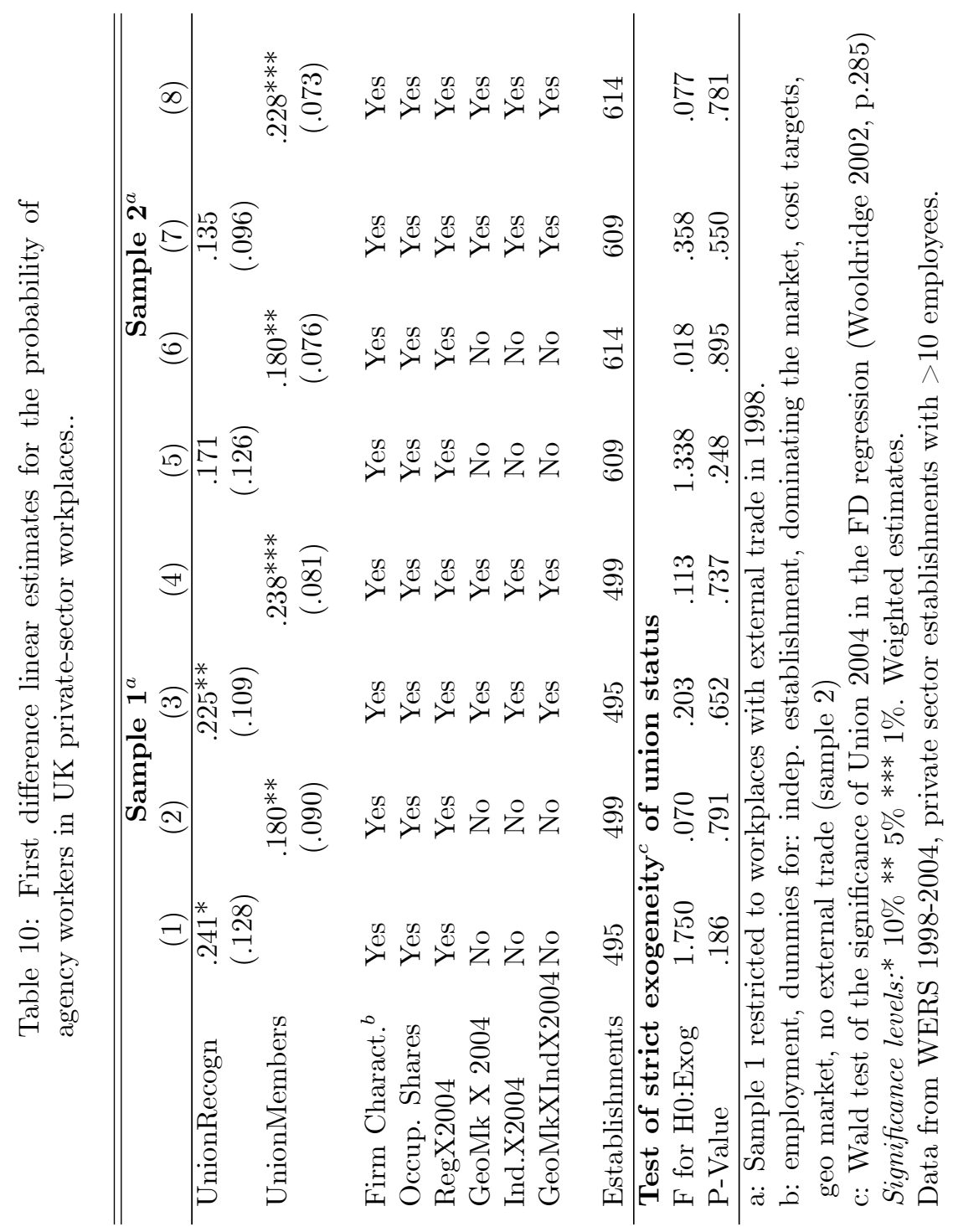


Table 11: OLS within-firm estimates for the probability of fixedterm workers in a given occupation.

\begin{tabular}{|c|c|c|c|c|c|c|c|c|c|}
\hline & $(1)$ & $(2)$ & $(3)$ & $(4)$ & $(5)$ & $(6)$ & $(7)$ & $(8)$ & $(9)$ \\
\hline AnyBarg & $\begin{array}{l}.011 \\
(.031)\end{array}$ & $\begin{array}{l}.018 \\
(.034)\end{array}$ & $\begin{array}{l}.006 \\
(.033)\end{array}$ & & & & & & \\
\hline UnionMemb & & & & $\begin{array}{l}.046 \\
(.032)\end{array}$ & $\begin{array}{l}.026 \\
(.033)\end{array}$ & $\begin{array}{l}.021 \\
(.039)\end{array}$ & & & \\
\hline LOCXAnyBarg & & $\begin{array}{l}-.057 \\
(.057)\end{array}$ & $\begin{array}{l}-.032 \\
(.064)\end{array}$ & & & & & & \\
\hline LOCXUnion & & & & & $\begin{array}{l}.019 \\
(.048)\end{array}$ & $\begin{array}{l}.056 \\
(.055)\end{array}$ & & & \\
\hline IndustryBarg & & & & & & & $\begin{array}{l}.016 \\
(.053)\end{array}$ & $\begin{array}{l}-.026 \\
(.047)\end{array}$ & $\begin{array}{l}-.012 \\
(.050)\end{array}$ \\
\hline OrgBarg & & & & & & & $\begin{array}{l}.010 \\
(.032)\end{array}$ & $\begin{array}{l}.051 \\
(.037)\end{array}$ & $\begin{array}{l}.044 \\
(.040)\end{array}$ \\
\hline LocalBarg & & & & & & & $\begin{array}{c}.007 \\
(.053)\end{array}$ & $\begin{array}{l}-.032 \\
(.073)\end{array}$ & $\begin{array}{l}-.062 \\
(.074)\end{array}$ \\
\hline LOCXIndustryBar & & & & & & & & $\begin{array}{l}.064 \\
(.094)\end{array}$ & $\begin{array}{l}.077 \\
(.105)\end{array}$ \\
\hline LOCXOrgBarg & & & & & & & & $\begin{array}{c}-.203^{* * *} \\
(.064)\end{array}$ & $\begin{array}{c}-.183^{* *} \\
(.072)\end{array}$ \\
\hline LOCXLocalBarg & & & & & & & & $\begin{array}{l}.065 \\
(.115)\end{array}$ & $\begin{array}{l}.079 \\
(.127)\end{array}$ \\
\hline Occ. Controls ${ }^{a}$ & Yes & Yes & Yes & Yes & Yes & Yes & Yes & Yes & Yes \\
\hline LOC Inter. ${ }^{b}$ & No & Yes & Yes & No & Yes & Yes & No & Yes & Yes \\
\hline Abs\&Resign $^{c}$ & No & No & Yes & No & No & Yes & No & No & Yes \\
\hline $\begin{array}{l}\text { Occup. dum- } \\
\text { mies }\end{array}$ & Yes & Yes & Yes & Yes & Yes & Yes & Yes & Yes & Yes \\
\hline IndXLOC & No & Yes & Yes & No & Yes & Yes & No & Yes & Yes \\
\hline RegXLOC & No & Yes & Yes & No & Yes & Yes & No & Yes & Yes \\
\hline OccupXLOC & No & Yes & Yes & No & Yes & Yes & No & Yes & Yes \\
\hline Firms & 1432 & 1382 & 1120 & 1411 & 1361 & 1102 & 1432 & 1382 & 1120 \\
\hline Occupations & 4982 & 4848 & 3937 & 4901 & 4765 & 3865 & 4982 & & \\
\hline
\end{tabular}

Dep Var: 1 if any fixed-term workers, 0 if none.

a: occupation employment size, dummy for largest occupation (LOC).

b: dummies for new workers in LOC to learn the job and LOC dummy interacted with firm-level controls. c: LOC dummy interacted with: perc. days lost due to absence in the firm, share of quits over last $12 \mathrm{~m}$. Significance levels:* $10 \% * * 5 \% * * * 1 \%$

Weighted estimates, standard errors account for complex design.

Data from WERS 2004, private sector firms with >10 employees. 
Table 12: Wald tests for the effect of union on $\operatorname{Pr}(\mathrm{FixT})$ in the largest occupation (LOC).

\begin{tabular}{|c|c|c|c|c|c|c|}
\hline & \multicolumn{3}{|c|}{ Spec $1^{a}$} & \multicolumn{3}{|c|}{ Spec $2^{a}$} \\
\hline & $\begin{array}{c}\text { Estimate } \\
(1)\end{array}$ & $\begin{array}{c}\text { F Stat } \\
(2)\end{array}$ & $\begin{array}{c}\text { P Value } \\
(3)\end{array}$ & $\begin{array}{c}\text { Estimate } \\
(4)\end{array}$ & F Stat & $\begin{array}{c}\text { P Value } \\
(6)\end{array}$ \\
\hline AnyBarg & -.039 & .577 & .448 & -.026 & .205 & .651 \\
\hline UnionMemb & .045 & .982 & .322 & .077 & 2.141 & .144 \\
\hline IndustryBarg & .037 & .181 & .671 & .064 & .477 & .490 \\
\hline OrgBarg & -.152 & 6.408 & .011 & -.138 & 3.941 & .047 \\
\hline LocalBarg & .032 & .144 & .704 & .016 & .034 & .854 \\
\hline
\end{tabular}

a: spec 1 controls for Resign and Absence, spec 2 does not.

Weighted estimates, standard errors account for complex design.

Data from WERS 2004, private sector firms with >10 employees. 
Table 13: OLS within-firm estimates for the probability of agency workers in a given occupation.

\begin{tabular}{|c|c|c|c|c|c|c|c|c|c|}
\hline & (1) & (2) & (3) & (4) & (5) & (6) & (7) & (8) & (9) \\
\hline AnyBarg & $\begin{array}{l}.049 \\
(.037)\end{array}$ & $\begin{array}{l}.047 \\
(.038)\end{array}$ & $\begin{array}{l}.022 \\
(.040)\end{array}$ & & & & & & \\
\hline UnionMemb & & & & $\begin{array}{l}.033^{*} \\
(.018)\end{array}$ & $\begin{array}{l}.030 \\
(.020)\end{array}$ & $\begin{array}{l}.037 \\
(.023)\end{array}$ & & & \\
\hline LOCXAnyBarg & & $\begin{array}{l}.020 \\
(.043)\end{array}$ & $\begin{array}{l}.041 \\
(.048)\end{array}$ & & & & & & \\
\hline LOCXUnion & & & & & $\begin{array}{l}.011 \\
(.029)\end{array}$ & $\begin{array}{l}.031 \\
(.033)\end{array}$ & & & \\
\hline IndustryBarg & & & & & & & $\begin{array}{c}.002 \\
(.033)\end{array}$ & $\begin{array}{c}.053 \\
(.050)\end{array}$ & $\begin{array}{l}.043 \\
(.050)\end{array}$ \\
\hline OrgBarg & & & & & & & $\begin{array}{l}-.032 \\
(.068)\end{array}$ & $\begin{array}{l}-.032 \\
(.061)\end{array}$ & $\begin{array}{l}-.049 \\
(.063)\end{array}$ \\
\hline LocalBarg & & & & & & & $\begin{array}{l}.149^{* * *} \\
(.050)\end{array}$ & $\begin{array}{l}.081 \\
(.052)\end{array}$ & $\begin{array}{l}.062 \\
(.055)\end{array}$ \\
\hline LOCXIndustryBar & & & & & & & & $\begin{array}{l}-.128 \\
(.082)\end{array}$ & $\begin{array}{l}-.113 \\
(.086)\end{array}$ \\
\hline LOCXOrgBarg & & & & & & & & $\begin{array}{l}.014 \\
(.054)\end{array}$ & $\begin{array}{l}.045 \\
(.062)\end{array}$ \\
\hline LOCXLocalBarg & & & & & & & & $\begin{array}{l}.162^{* *} \\
(.072)\end{array}$ & $\begin{array}{l}.185^{* *} \\
(.072)\end{array}$ \\
\hline Occ. Controls ${ }^{a}$ & Yes & Yes & Yes & Yes & Yes & Yes & Yes & Yes & Yes \\
\hline LOC Inter. ${ }^{b}$ & No & Yes & Yes & No & Yes & Yes & No & Yes & Yes \\
\hline Abs\&Resign $^{c}$ & No & No & Yes & No & No & Yes & No & No & Yes \\
\hline $\begin{array}{l}\text { Occup. dum- } \\
\text { mies }\end{array}$ & Yes & Yes & Yes & Yes & Yes & Yes & Yes & Yes & Yes \\
\hline IndXLOC & No & Yes & Yes & No & Yes & Yes & No & Yes & Yes \\
\hline RegXLOC & No & Yes & Yes & No & Yes & Yes & No & Yes & Yes \\
\hline OccupXLOC & No & Yes & Yes & No & Yes & Yes & No & Yes & Yes \\
\hline Firms & 1440 & 1387 & 1122 & 1419 & 1366 & 1104 & 1440 & 1387 & 1122 \\
\hline Occupations & 5023 & 4874 & 3949 & 4943 & 4792 & 3878 & 5023 & 4874 & 3949 \\
\hline
\end{tabular}

Dep Var: 1 if any agency workers, 0 if none.

a: occupation employment size, dummy for largest occupation (LOC).

b: dummies for new workers in LOC to learn the job and LOC dummy interacted with firm-level controls. c: LOC dummy interacted with: perc. days lost due to absence in the firm, share of quits over last $12 \mathrm{~m}$. Significance levels:* $10 \% * * 5 \% * * * 1 \%$

Weighted estimates, standard errors account for complex design.

Data from WERS 2004, private sector firms with >10 employees. 
Table 14: Wald tests for the effect of union on $\operatorname{Pr}(\mathrm{TAW})$ in the largest occupation (LOC).

\begin{tabular}{|c|c|c|c|c|c|c|}
\hline & \multicolumn{3}{|c|}{ Spec $1^{a}$} & \multicolumn{3}{|c|}{ Spec $2^{a}$} \\
\hline & $\begin{array}{c}\text { Estimate } \\
(1)\end{array}$ & $\begin{array}{c}\text { F Stat } \\
(2)\end{array}$ & $\begin{array}{c}\text { P Value } \\
(3)\end{array}$ & $\begin{array}{c}\text { Estimate } \\
(4)\end{array}$ & F Stat & $\begin{array}{c}\text { P Value } \\
(6)\end{array}$ \\
\hline AnyBarg & .067 & 1.937 & .164 & .063 & 1.379 & .241 \\
\hline UnionMemb & .041 & 2.379 & .123 & .068 & 5.602 & .018 \\
\hline IndustryBarg & -.075 & 1.583 & .209 & -.070 & 1.252 & .263 \\
\hline OrgBarg & -.018 & .044 & .834 & -.004 & .002 & .968 \\
\hline LocalBarg & .243 & 11.928 & .001 & .246 & 9.087 & .003 \\
\hline
\end{tabular}

a: spec 1 controls for Resign and Absence, spec 2 does not.

Weighted estimates, standard errors account for complex design.

Data from WERS 2004, private sector firms with $>10$ employees. 


\section{Specification using the panel sample}

1. I use two measures of unionisation. The first one, UnionRecogn, is a dummy is at least one union is recognized (either at the workplace or at a higher level in the same organization). The second one is a dummy indicating whether there are any union members in the workplace.

2. TotalEmpl and the share of employment in each occupation. The latter should control for the fact that firms might be more likely to use temporary contracts in specific occupations. I also have occupational dummies taking the value of 1 if that occupation is the largest in the firm.

3. A dummy for independent establishments. The question is asked consistently in the two years and there are no apparent comparability issues. There is some time-series variation in the variable.

4. Geographical market: dummies for local/regional/national/international market. In 1998 establishments that did not trade externally were not asked this question. In 2004 the question was asked of all the establishments. Moreover, in 2004 there is no question that allows to distinguish establishments that did not trade externally. As a result, about 120 establishments in the private sector have missing values on these dummies for $1998^{19}$. I therefore constructed two versions of these dummies. The first one simply treats establishments not trading in 1998 as missing values, effectively excluding them from the sample. The second version assumes that those establishments that were not trading in 1998 continued not to trade in 2004. Therefore all of these (second version) dummies are set equal to zero for these establishments. To account for additional (time varying) systematic differences between firms not trading and the rest, I also constructed a dummy (NoTrade98) which is 1 if the workplace was not trading externally in 1998 and zero otherwise (including all the 2004 observations). This is equivalent to an interaction between a dummy for not trading and a year dummy for 1998. Under the assumption that there was no change in NoTrade (so that the dummy itself does not appear in a regression in first-difference), this additional variable captures the changing effect over time of not trading externally.

5. A dummy for dominating the market and one for dominating or having few competitors (less than 5). This is the best measure of market power that I can use in the panel exercise because, unlike the 2004 cross-sectional dataset, the panel dataset does not provide information on different market shares ${ }^{20}$.

6. Following the same logic described in previous sections, I have built a few interactions to try and capture changes in uncertainty to which a firm may be exposed. In particular, I allow interactions between (1) industry and time dummies and (2) geographical market dummies ${ }^{21}$ and time dummies and (3) region and time dummies. Also a triple interaction between industry dummies, geographical market dummies and the year dummy for 2004 is included. In this way, I hope to capture the change over time in the level of uncertainty affecting firms belonging to the same industry/region or trading on markets of similar extension.

\section{References}

Addison, J. T., P. Teixeira, and T. Zwick (2006). Works councils and the anatomy of wages. IZA Discussion Papers 2474, Institute for the Study of Labor (IZA).

\footnotetext{
${ }^{19}$ There are some workplaces which were not trading in 1998 which do have an aswer of 2004. If they conserved their non-trading status in 2004, presumably the answer for that year refers to the company to which they belong.

${ }^{20}$ Note that as for the geographical market dummies, this variable is missing in 1998 for non-trading establishments. Unlike the regional market dummies, however, I constructed only one version of this variable which forces the establishments not trading in 1998 to have value zero in both years. Clearly when these variables are included with the first version of the geographical market dummies described above, the observations with missing values in 1998 are effectively excluded from the sample anyway.

${ }^{21}$ The geo-market dummies employed are the ones where non-trading establishments are set equal to zero.
} 
Angrist, J. D. (2001, January). Estimations of limited dependent variable models with dummy endogenous regressors: Simple strategies for empirical practice. Journal of Business 8 Economic Statistics 19(1), 2-16.

Angrist, J. D. and J.-S. Pischke (2009). Mostly harmless econometrics. Princeton University Press.

Arulampalam, W. and A. L. Booth (December 1998). Training and labour market flexibility: Is there a trade-off? British Journal of Industrial Relations 36, 521-536(16).

Arulampalam, W., A. L. Booth, and M. L. Bryan (2004). Training in Europe. Journal of the European Economic Association 2(2-3), 346-360.

Autor, D. H. (2003, January). Outsourcing at will: The contribution of unjust dismissal doctrine to the growth of employment outsourcing. Journal of Labor Economics 21(1), $1-42$.

Autor, D. H. and S. N. Houseman (2002). Do temporary help jobs improve labor market outcomes? A pilot analysis with welfare clients. MITmimeo.

Autor, D. H. and S. N. Houseman (2008). Do temporary help jobs improve labor market outcomes for low-skilled workers? evidence from Work First. MITmimeo.

Bentolila, S. and J. Dolado (1994). Labour flexibility and wages: Lessons from Spain. Economic Policy 9(18), 55-99.

Blanchard, O. and A. Landier (2002). The perverse effects of partial labour market reform: fixed-term contracts in France. Economic Journal 112(480), F214-F244.

Booth, A. L. (1995). The Economics of Trade Union. Cambridge: Cambridge University Press.

Booth, A. L., J. J. Dolado, and J. Frank (2002, June). Symposium on temporary work introduction. Economic Journal 112(480), F181-F188.

Booth, A. L. and M. Francesconi (2003, July). Union coverage and non-standard work in Britain. Oxford Economic Papers 55(3), 383-416.

Booth, A. L., M. Francesconi, and J. Frank (2002, June). Temporary jobs: Stepping stones or dead ends? Economic Journal 112(480), F189-F213.

Brunello, G., P. Garibaldi, and E. Wasmer (2007). Education and Training in Europe. Oxford: Oxford University Press. 
Bryson, A. (2007). Temporary agency workers and workplace performance in the private sector. Manpower Human Resources Lab Discussion Paper, London School of Economics 3.

Cahuc, P. and A. Zylberberg (2004). Labor Economics. Cambridge, MA: MIT Press.

Chaplin, J., J. Mangla, S. Purdon, and C. Airey (2004). Wers 2004 technical report. Technical report, Department of Trade and Industry.

ETUI-REHS (2008). Worker-participation.eu.

Francesconi, M. and C. Garcia-Serrano (October 2004). Unions and flexible employment in Britain and Spain: A descriptive note. Industrial Relations 43, 874-882(9).

Gramm, C. L. and J. F. Schnell (2001). The use of flexible staffing arrangements in core production jobs. Industrial and Labor Relations Review 54 (2), 245-258.

Guell, M. and B. Petrongolo (2007, April). How binding are legal limits? transitions from temporary to permanent work in Spain. Labour Economics 14 (2), 153-183.

Hamermesh, D. S. (1996). Labor Demand. Princeton University Press.

Houseman, S. N. (2001). Why employers use flexible staffing arrangements: Evidence from an establishment survey. Industrial and Labor Relations Review 55(1), 149-170.

Ichino, A., F. Mealli, and T. Nannicini (2008). From temporary help jobs to permanent employment: what can we learn from matching estimators and their sensitivity? Journal of Applied Econometrics 23(3), 305-327.

Kahn, L. M. (2007, 06). The impact of employment protection mandates on demographic temporary employment patterns: International microeconomic evidence. Economic Journal 117(521), 333-356.

Layard, R., S. Nickell, and R. Jackman (2005). Unemployment: Macroeconomic Performance and the Labour Market. Oxford University Press.

Medoff, J. L. (1979). Layoffs and alternatives under trade unions in U.S. manufacturing. American Economic Review 69(3), 380-95.

OECD (2002). Employment Outlook. Paris: OECD.

OECD (2004). Employment Outlook. Paris: OECD.

OECD (2008). Employment Outlook. Paris: OECD. 
Rivers, D. and Q. H. Vuong (1988, November). Limited information estimators and exogeneity tests for simultaneous probit models. Journal of Econometrics 39(3), 347-366.

Verma, A. (2003, August). What do unions do to the workplace? Union effects on management and HRM policies. Journal of Labor Research 26(3), 415-449.

Wooldridge, J. (2002). Econometric analysis of cross section and panel data. The MIT Press. 